\title{
ANALYSIS OF PROTEIN ADDUCTS AS BIOMARKERS OF SHORT-TERM EXPOSURE TO ETHYLENE OXIDE AND RESULTS OF FOLLOW-UP BIOMONITORING*
}

\author{
Michael BADER, Wolfgang WILL, Gunild FREY, and Michael NASTERLACK
}

BASF SE, Occupational Medicine \& Health Protection, Ludwigshafen, Germany

Received in January 2012

CrossChecked in May 2012

Accepted in May 2012

\begin{abstract}
An accidental exposure of six workers to ethylene oxide (EO) provided the rationale for a biomonitoring and follow-up study, whose aim was to analyse protein adduct kinetics and examine the differentiation between accidental and environmental exposure, e.g., from tobacco smoke. For this purpose, the decrease in the concentration of the haemoglobin adduct $N$-2-hydroxyethylvaline (HEV) was followed during a five-month period after the accident, together with $N$-2-cyanoethylvaline (CEV) and urinary cotinine, two well-established biomarkers for smoking. The follow-up study showed that EO adduct concentrations significantly increased after a short but presumably high exposure. Initial biomonitoring revealed HEV levels above $500 \mathrm{pmol} \mathrm{g}^{-1}$ globin in all cases, with a maximum of about $2,400 \mathrm{pmol} \mathrm{g}^{-1}$ globin. This compares to a German EKA value (exposure equivalent for carcinogenic substances) for a daily 8-h-exposure to $1 \mathrm{ppm}$ EO of $90 \mu \mathrm{g} \mathrm{L}^{-1}$ blood ( 3,900 $\mathrm{pmol} \mathrm{g}^{-1}$ globin). The adduct levels dropped in accordance with the expected zero-order kinetics for a single exposure. After the five-month observation interval, the HEV concentrations in blood reflected the individual background from tobacco smoking. The results of this study show that even a short exposure to ethylene oxide may result in a significant rise in haemoglobin adduct levels. Although protein adducts and their occupational-medical assessment values are considered for long-term exposure surveillance, they can also be used for monitoring accidental exposures. In these cases, the calculation of daily 'ppm-equivalents' may provide a means for a comparison with the existing assessment values.
\end{abstract}

KEY WORDS: accidental exposure, haemoglobin adduct kinetics, occupational exposure

Ethylene oxide (EO) is an important chemical intermediate mainly used for the synthesis of ethylene glycol and its ethers, ethoxylates, ethanolamines, polyoles, and polyesters, or for sterilisation purposes (1). Its acute toxic properties comprise moderate irritation of the eye, the mucous membranes, and the upper respiratory tract with typical symptoms of exposure being headache, dizziness, nausea, and

* Partly presented at the $39^{\text {th }}$ International MEDICHEM Congress on Occupational and Environmental Health in the Production and Use of Chemicals "Occupational Health in a Changing World", Heidelberg, Germany, 2 - 5 June 2011 vomiting. $\mathrm{EO}$ is a known animal carcinogen and a suspected human carcinogen $(2,3)$. Due to its hazardous potential, ethylene oxide is usually handled and reacted in closed systems. Its use for sterilisation purposes, e.g., in hospitals and in the production of sterile disposable medical equipment, is strictly controlled in Germany by technical guidelines, and biological monitoring is recommended for health surveillance (4-7).

Ethylene oxide is readily absorbed either by inhalation or through the skin (skin notation). The main metabolic pathway of EO involves a hydrolysis 
of the epoxide to yield ethylene glycol and a subsequent sequential oxidation to oxalate, formiate and carbon dioxide, or an enzymatically mediated conjugation to glutathione to form $S$-2-hydroxyethyl mercapturic acid $(8,9)$. In addition, ethylene oxide binds spontaneously to nucleophilic acids in proteins, namely to haemoglobin in blood. One of these covalently bound addition products, or 'adducts', is the N-terminal $N$-2-hydroxyethylvaline (HEV), a well-established biomarker for ethylene oxide exposure (10-12). In Germany, the Senate Commission for the Investigation of Health Hazards in the Work Area of the German Research Foundation (Deutsche Forschungsgemeinschaft - DFG) has established socalled 'exposure equivalents for carcinogenic substances' (EKA), which describe the correlation between ethylene oxide concentrations in air and HEV concentrations in blood (13). A confounder for this biomarker is smoking, as ethylene oxide is a metabolite of ethene in tobacco smoke (14-16). While nonsmokers usually show HEV levels below $75 \mathrm{pmol} \mathrm{g}^{-1}$ globin, levels up to $550 \mathrm{pmol} \mathrm{g}^{-1}$ globin are observed in blood samples from smokers (17). One specific aspect in the interpretation of adduct biomonitoring is the fact that assessment and reference values are based on steadystate concentrations. These are achieved only after a regular exposure for at least 120 days, which corresponds to the average life-span of the erythrocytes (18-21). Under constant exposure conditions, the adduct levels continue to increase during this interval until the equilibrium between daily increment of adducts and erythrocyte breakdown has been reached. While protein adducts are valuable markers of a longterm integrated dose, measurement and interpretation of adduct levels after intermittent or single exposures have not yet been well established. In the context of isolated accidental exposures, it would also be interesting to see if the decline of adduct levels follows the expected linear function until the baseline level, e.g., associated mainly with regular smoking habits, has been reached after 120 days. In this case, an extrapolation of adduct concentrations, which were measured weeks or even months after the exposure, would be both possible and advantageous, as it offers a broader time-frame for sample collection than most other biomarkers.

In a study following an accidental exposure of six workers to ethylene oxide in a chemical plant, we investigated the degradation kinetics of the haemoglobin adduct HEV during a period of five months. Furthermore, we calculated the additional exposure following the accident and developed an approach for the interpretation of adduct levels after single or short-term exposures. As the individual background levels from tobacco smoking are to be considered for HEV interpretation, urinary cotinine and $N$-2-cyanoethylvaline (a haemoglobin adduct of acrylonitrile in tobacco smoke) were analysed $(17,22$, 23).

\section{MATERIALS AND METHODS}

\section{Study group and ethylene oxide exposure}

Six male workers from a chemical plant were accidentally exposed to ethylene oxide outside the building. About $40 \mathrm{~kg}$ of liquid EO were released through an open valve and evaporated into the surroundings. While there were no specific data available on the concentration of EO in air, the nearby gas alert system was activated, thus indicating that several hundred ppm of EO were detected in the vicinity of the building. Taking into account that the open valve was shut after 2 to $3 \mathrm{~min}$ and that a mobile measuring station did not detect any airborne $\mathrm{EO}$ after about $15 \mathrm{~min}$, the maximum exposure time of six workers was estimated to be 15 minutes. Immediately after the accidental exposure, the workers were taken care of in the out-patient clinic of the Occupational Medicine \& Health Protection Department of the company.

\section{Biomonitoring}

Blood and urine samples were collected in the out-patient clinic one day after the accident and thereafter on a monthly basis over a five-month interval. Blood samples were drawn into regular EDTA-containing disposable syringes (Monovettes ${ }^{\circledR}$, Sarstedt, Germany). The erythrocytes were separated from the plasma fraction by centrifugation $(800 \times \mathrm{g}$, $5 \mathrm{~min}$ ) and washed twice with isotonic saline (addition of $0.9 \%$ sodium chloride, centrifugation, removal of saline) until the supernatant was colourless and clear. The original sample volume was then restored by addition of ultrapure water, while the erythrocytes were lysed by this procedure. To monitor exposure to ethylene oxide and to the tobacco smoke contaminant acrylonitrile, the haemoglobin adducts $\mathrm{N}-2$ hydroxyethylvaline (HEV) and $N$-2-cyanoethylvaline (CEV) were quantified in these samples. The protein adduct analyses were carried out in an accredited and 
certified contract laboratory (Currenta, Leverkusen, Germany) essentially following a procedure described by van Sittert et al. (17). Globin was isolated from the haemolysates by fractionated precipitation. The dried protein was then subjected to the so-called 'modified or N-Alkyl-Edman method' (10): the adduct-bearing $\mathrm{N}$-terminal amino acid (HEV, CEV) was cleaved off of the protein chain and simultaneously derivatised with pentafluorophenyl isothiocyanate into a thiohydantoin. It was then extracted with diethyl ether, evaporated to dryness, and reconstituted in toluene. Subsequently, the samples were analysed by gas chromatography-mass spectrometry (GC-MS) in the electron impact mode.

Spot urine samples were collected in parallel to the blood specimens in $100 \mathrm{~mL}$ polystyrene containers. The nicotine metabolite cotinine was analysed in these samples in the biomonitoring laboratory of the Occupational Medicine \& Health Protection Department at BASF SE, Ludwigshafen, Germany, according to a method described by Müller et al. (24). Urine samples were alkalised with sodium hydroxide solution and extracted with dichloromethane after the addition of 2-benzylpyridine as internal standard. The extract was then analysed by GC-MS in the electron impact mode using selected ion monitoring. The method has been tested and certified within several round-robin tests of the German External Quality Assessment Scheme (G-EQUAS, c/o Institute of Occupational, Social and Environmental Medicine of the University of Erlangen-Nuremberg). To correct for diuretic variance, urinary creatinine was analysed by an HPLC-UV method (25) in the BASF laboratory. This parameter was also successfully certified within the G-EQUAS program.

\section{Data processing and calculations}

All calculations were carried out with either the Microsoft ${ }^{\circledR}$ Office Excel 2003 software package or with $\mathrm{IBM}^{\circledR}$ SPSS $^{\circledR}$ Statistics 19.0.

\section{RESULTS}

Four of the six workers exposed to ethylene oxide reported moderate acute effects: mild irritation of the mucous membranes and the upper respiratory tract, dizziness, shortness of breath, cough, and headache. Lung function testing of one worker revealed a slightly reduced peak flow. Two workers with pulmonary symptoms received intravenous corticoids for lung oedema prevention according to the established medical guidelines (26) and stayed in a clinic overnight for observation. Four days after the accidental exposure, two workers still reported general weariness and one of them felt a sunburn-like itchy feeling on some parts of his skin. All observed effects had completely resolved by the time the first follow-up biomonitoring investigation was carried out, four weeks after the accident.

As individual smoking habits are an important factor for further interpretation of the adduct levels of exposure to ethylene oxide, two biomarkers of tobacco smoke, urinary cotinine and haemoglobin adduct CEV, were analysed in order to confirm the self-reported smoker status of the employees (Table 1). Cotinine biomonitoring results for all self-reported smokers (study participants 1, 2, 3, 5, and 6) were always high above the reference values ( $95^{\text {th }}$ percentiles) of $16 \mu \mathrm{g} \mathrm{g}^{-1}$ creatinine for never-smokers and $53 \mu \mathrm{g} \mathrm{g}^{-1}$

Table 1 Results of N-2-cyanoethylvaline and cotinine analyses (-- no sample collected, n.d. not detectable, S smoker, NS nonsmoker)

\begin{tabular}{|c|c|c|c|c|c|c|c|c|}
\hline Worker & Biomarker & Sample 1 & Sample 2 & Sample 3 & Sample 4 & Sample 5 & Sample 6 & Average \\
\hline \multirow{2}{*}{$1(\mathrm{~S})$} & $\mathrm{CEV} / \mathrm{pmol} \mathrm{g}^{-1}$ globin & 212 & 192 & 204 & 94 & -- & 106 & 162 \\
\hline & cotinine / $\mu \mathrm{g} \mathrm{g}^{-1}$ creatinine & -- & -- & -- & 1,459 & -- & 2,649 & 2,054 \\
\hline \multirow{2}{*}{$2(\mathrm{~S})$} & $\mathrm{CEV} / \mathrm{pmol} \mathrm{g}^{-1}$ globin & 114 & 102 & 94 & 69 & 106 & 90 & 96 \\
\hline & cotinine / $\mu \mathrm{g} \mathrm{g}^{-1}$ creatinine & -- & 2,086 & 1,766 & 2,126 & 1,989 & 2,247 & 2,043 \\
\hline \multirow{2}{*}{$3(S)$} & CEV (pmol g-1 globin) & 147 & 147 & 106 & 53 & 114 & 69 & 106 \\
\hline & cotinine / $\mu \mathrm{g} \mathrm{g}^{-1}$ creatinine & -- & 6,244 & 1,577 & 752 & 1,132 & 3,879 & 2,717 \\
\hline \multirow{2}{*}{4 (NS) } & $\mathrm{CEV} / \mathrm{pmol} \mathrm{g}^{-1}$ globin & n.d. & n.d. & n.d. & n.d. & n.d. & n.d. & n.d. \\
\hline & cotinine / $\mu \mathrm{g} \mathrm{g}^{-1}$ creatinine & -- & 16 & 15 & 10 & 15 & -- & 14 \\
\hline \multirow{2}{*}{$5(\mathrm{~S})$} & $\mathrm{CEV} / \mathrm{pmol} \mathrm{g}^{-1}$ globin & 200 & 167 & 155 & 49 & 188 & 131 & 148 \\
\hline & cotinine / $\mu \mathrm{g} \mathrm{g}^{-1}$ creatinine & -- & 1,073 & 678 & 432 & 709 & 2,045 & 987 \\
\hline \multirow{2}{*}{$6(S)$} & $\mathrm{CEV} / \mathrm{pmol} \mathrm{g}^{-1}$ globin & 131 & 118 & 94 & 69 & 139 & 82 & 106 \\
\hline & cotinine $/ \mu \mathrm{g} \mathrm{g}^{-1}$ creatinine & -- & -- & 734 & 181 & 893 & 1,485 & 823 \\
\hline
\end{tabular}


creatinine for ex-smokers (Third German Environmental Survey) (27). Many samples showed cotinine levels above $1,000 \mu \mathrm{g} \mathrm{g}^{-1}$ creatinine, these results being well in the range of typical smokers. The German Federal Environment Agency reports a cotinine median of $998 \mu \mathrm{g} \mathrm{g}^{-1}$ creatinine and a $95^{\text {th }}$ percentile of $3,340 \mu \mathrm{g} \mathrm{g}^{-1}$ creatinine for a representative sample of smokers $(\mathrm{n}=1,605)(27)$. The individual smoking status was further confirmed by the CEV analyses: all adduct levels were above $50 \mathrm{pmol} \mathrm{g}^{-1}$ globin, whereas nonsmokers normally show CEV levels below $10 \mathrm{pmol} \mathrm{g}^{-1}$ globin (13). Only one worker (study participant 4) declared himself a nonsmoker and biomonitoring results confirmed this: CEV was not detectable in blood samples of this employee and the cotinine levels were between $10 \mu \mathrm{g} \mathrm{g}^{-1}$ and $14 \mu \mathrm{g}$ $\mathrm{g}^{-1}$ creatinine. Both tobacco smoke related biomarkers showed a distinct intra-individual variation during the study interval, with a larger variability of the shortterm biomarker cotinine (average: $53 \%$ ) as compared to the protein adduct CEV (average: $30 \%$ ).

The results of the initial and follow-up biomonitoring of HEV in the six workers are summarised in Table 2. The adduct levels observed one day after the accidental exposure (four days in one case) ranged between $522 \mathrm{pmol} \mathrm{g}^{-1}$ and 2,396 $\mathrm{pmol} \mathrm{g}^{-1}$. Every worker provided five more samples in the following four months (one sampling time was missed by study participant 1), however not always strictly according to the scheduled 30-day intervals. Nevertheless, the follow-up data showed the expected decline in individual HEV concentrations until the sixth sampling, which took place after 162 days (166 days in one case). The smokers still showed HEV levels in a range between $151 \mathrm{pmol} \mathrm{g}^{-1}$ and $276 \mathrm{pmol} \mathrm{g}^{-1}$ globin at the end of the study; this is consistent with typical smoker values as reported, for example, by van Sittert et al. (17), Bader et al. (16) and Schettgen et al. (22). This also confirms the results of biomonitoring for urinary cotinine and $\mathrm{CEV}$. In contrast, the nonsmoking employee revealed an HEV level of only $30 \mathrm{pmol} \mathrm{g}^{-1}$ globin. According to Törnqvist et al. (28), background levels of HEV in nonsmokers are probably associated with ethene production by intestinal bacteria. Typical $\mathrm{HEV}$ levels in nonsmokers are below $50 \mathrm{pmol} \mathrm{g}^{-1}$ globin $(16,17,22)$.

Due to the average life-span of human erythrocytes of about 120 days, the final HEV concentration of every individual more than 160 days after the accidental exposure was regarded as the tobacco smoke and intestinal ethene related background. This value was therefore subtracted from the initially measured adduct concentration in order to calculate the impact of the additional accidental exposure on HEV levels (Table 3). According to the German EKA values for ethylene oxide, a daily exposure to $1 \mathrm{ppm}$ $\left(1830 \mu \mathrm{g} \mathrm{m}^{-3}\right)$ EO corresponds to an HEV level of approximately $3,900 \mathrm{pmol} \mathrm{g}^{-1}$ globin under steadystate conditions (13), which in turn reflects the average exposure of 60 working days (12). Therefore, an increment of $3,900 / 60=65 \mathrm{pmol} \mathrm{g}^{-1}$ per 8 -h-exposure day can be calculated and used to derive 'ppmequivalents' from the adduct concentrations related to accidental exposure. Following this approach, the adduct levels of the exposed workers correspond to 5 to 36 'ppm-equivalents'.

To analyse adduct kinetics, the initial HEV results were individually adjusted to $100 \%$ after subtraction of the respective background values (Figure 1). A cubic fit $\left(\mathrm{R}^{2}=0.950, \mathrm{p}<0.001\right)$ was applied in this case

Table 2 Results of N-2-hydroxyethylvaline adduct analyses (-- no sample collected)

\begin{tabular}{|c|c|c|c|c|c|c|c|}
\hline Worker & Biomarker & Sample 1 & Sample 2 & Sample 3 & Sample 4 & Sample 5 & Sample 6 \\
\hline \multirow{2}{*}{1} & days post-exposure & 1 & 5 & 28 & 84 & -- & 166 \\
\hline & $\mathrm{HEV} / \mathrm{pmol} \mathrm{g}^{-1}$ globin & 1,961 & 1,849 & 1,573 & 513 & -- & 164 \\
\hline \multirow{2}{*}{2} & days post-exposure & 1 & 28 & 55 & 85 & 140 & 162 \\
\hline & $\mathrm{HEV} / \mathrm{pmol} \mathrm{g}^{-1}$ globin & 522 & 418 & 284 & 259 & 259 & 207 \\
\hline \multirow{2}{*}{3} & days post-exposure & 1 & 28 & 55 & 85 & 127 & 162 \\
\hline & $\mathrm{HEV} / \mathrm{pmol} \mathrm{g}^{-1}$ globin & 771 & 694 & 440 & 332 & 272 & 233 \\
\hline \multirow{2}{*}{4} & days post-exposure & 1 & 28 & 55 & 85 & 127 & 162 \\
\hline & $\mathrm{HEV} / \mathrm{pmol} \mathrm{g}^{-1}$ globin & 2,396 & 1,862 & 1,082 & 560 & 142 & 30 \\
\hline \multirow{2}{*}{5} & days post-exposure & 4 & 28 & 55 & 85 & 127 & 162 \\
\hline & $\mathrm{HEV} / \mathrm{pmol} \mathrm{g}^{-1}$ globin & 642 & 595 & 315 & 319 & 332 & 276 \\
\hline \multirow{2}{*}{6} & days post-exposure & 1 & 5 & 55 & 85 & 127 & 162 \\
\hline & $\mathrm{HEV} / \mathrm{pmol} \mathrm{g}^{-1}$ globin & 970 & 965 & 392 & 319 & 220 & 151 \\
\hline
\end{tabular}


Table 3 Initial, tobacco smoke and accidental exposure related HEV concentrations and calculation of 'ppm-equivalents' (ppm-equivalents calculated by dividing the additional accidental exposure by the daily increment of 65 pmol $g^{-1}$ globin $\times$ day)

\begin{tabular}{lcccc}
\hline Worker & $\begin{array}{c}\text { HEV / } \\
\text { pmol g- } \mathbf{~ g l o b i n ~} \\
\text { first sample }\end{array}$ & $\begin{array}{c}\text { HEV / } \\
\text { pmol g } \mathbf{~}^{\mathbf{1}} \text { globin } \\
\text { last sample }\end{array}$ & $\begin{array}{c}\text { HEV / } \\
\text { pmol } \mathbf{g}^{-1} \text { globin } \\
\text { accidental exposure }\end{array}$ & $\begin{array}{c}\text { ppm- } \\
\text { equivalents }\end{array}$ \\
\hline 1 & 2,396 & 30 & 2,366 & 36 \\
\hline 2 & 1,961 & 164 & 1,797 & 30 \\
\hline 3 & 970 & 151 & 819 & 8 \\
\hline 5 & 771 & 233 & 538 & 6 \\
\hline 6 & 658 & 276 & 382 & 5 \\
\hline
\end{tabular}

to visualise the reduction of adduct concentrations and its confidence interval. It is noteworthy that after more than 120 days the HEV values were still higher than the final background values ( $>160$ days). This was also the case with the nonsmoking study participant, thus pointing to a fraction of exposed erythrocytes with a longer than average life-span. According to the assumption of a constant adduct decline following zero-order kinetics during the first 120 days $(12,21)$, all adjusted $\mathrm{HEV}$ results between initial biomonitoring and 130 days post-exposure were subjected to a linear regression analysis (Figure 2). The resulting linear fit was y $(\%$ of the initial HEV concentration after a single exposure $)=-0.81(0.68$ to 0.94$) \times($ days postexposure) + 95 (86 to 104) (with $\mathrm{R}^{2}=0.865, \mathrm{p}<0.001$, numbers in brackets $=95 \%$ confidence intervals). According to this equation, the concentration of $\mathrm{HEV}$ after one-time exposure decreases constantly at a rate

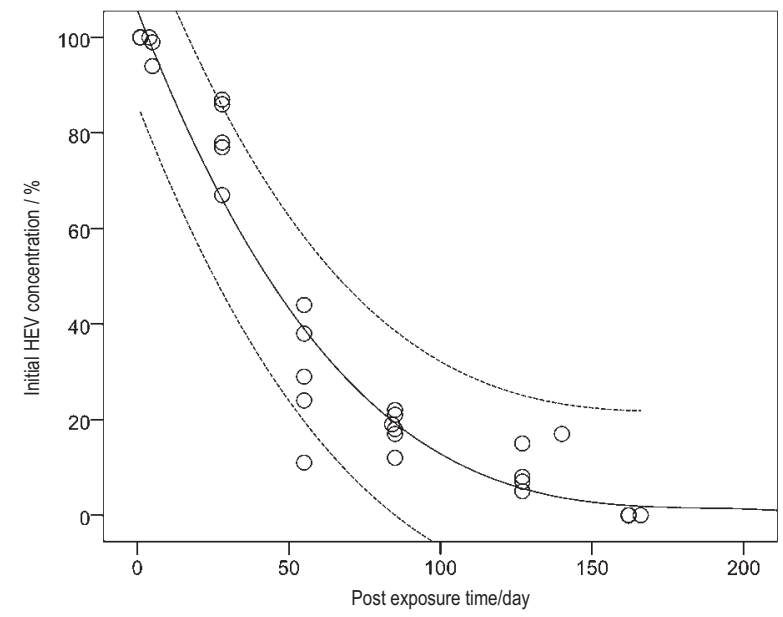

Figure 1 Time-course of ethylene oxide adducts (cubic fit and $95 \%$ confidence intervals, $y=-1.647 x+0.009 x^{2}$ $-0.00002 x^{3}+106, R^{2}=0.950, p<0.001 ; H E V$ adjusted for background exposure and related to initial adduct concentration)

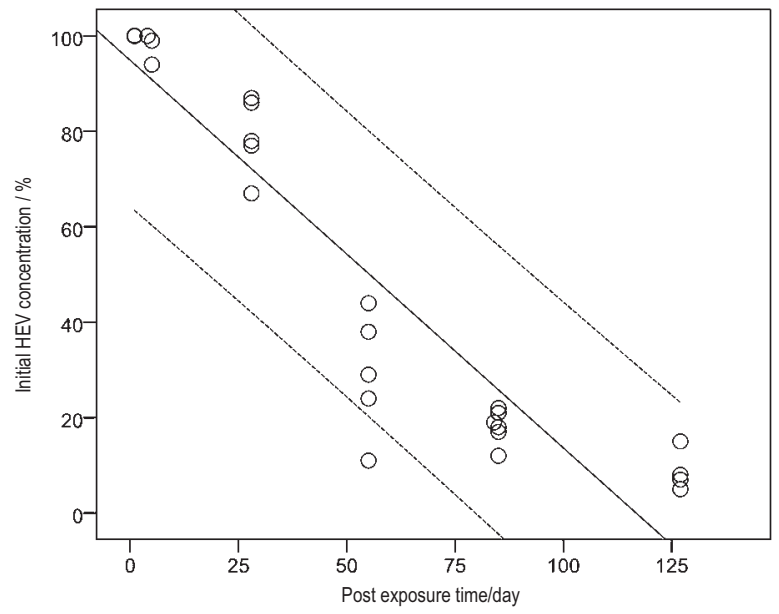

Figure 2 Linear regression fit of ethylene oxide adducts during the first 130 days post-exposure $(y=-0.81 \times$ (days) + 95, R2 $=0.865, p<0.001 ;$ HEV adjusted for background exposure and related to initial adduct concentration)

of $0.81 \%$ of the initial value per day until the background level is reached after 95/0.81=117 days (or 123 days, in case only the slope of the curve is considered).

\section{DISCUSSION}

Six workers of a chemical plant were exposed during a period of approximately $15 \mathrm{~min}$ to vaporous ethylene oxide. Although no data on the exposure intensity were available, a rough estimate was made that about $40 \mathrm{~kg}$ of liquid EO were released and vapourised rapidly. Ethylene oxide is heavier than air and its distribution within a radius of $50 \mathrm{~m}$ and up to a height of $5 \mathrm{~m}\left(\sim 39,270 \mathrm{~m}^{3}\right)$ would result in a mean concentration of about $1,000 \mathrm{mg} \mathrm{m}^{-3}$ or $500 \mathrm{ppm}$, 
respectively. This estimated concentration is far above the previous German Technical Guideline Concentration (TRK) for EO of $1 \mathrm{ppm}$ and would explain why the gas alert system in the vicinity of the leak was triggered. Also, the irritative effects and pulmonary symptoms experienced by four workers are consistent with a short but high exposure to ethylene oxide (2).

First of all, ethylene oxide adducts were monitored in order to identify exposed workers and to provide a quantitative measure for the exposure intensity. As the initially measured adduct concentrations were considered to be fairly high in relation to the short exposure time, follow-up biomonitoring was implemented and adduct kinetics was studied to confirm the association of adduct concentrations with the accidental exposure. It was assumed that additional adduct levels would attenuate in a linear fashion down to background levels within 120 days, in accordance with zero-order kinetics $(12,21,29)$. While the constant decrease of haemoglobin adducts after a single, or accidental, exposure can be estimated on the basis of the known life-span of erythrocytes, reports on this aspect from human in vivo studies are scarce $(30,31)$. In theory, a single exposure to ethylene oxide during one work shift leads to the formation of covalently bound and chemically stable adducts to erythrocyte haemoglobin in the blood. The total erythrocyte population in humans at a given point in time comprises an equally distributed number of cells between one day and a maximum of 120 days of age, which is the typical life-span of an erythrocyte. After the exposure event, the adducts are removed together with the haemoglobin and erythrocytes at a theoretical rate of $1 / 120 \times 100=0.83$ percent per day until, after about 120 days, all adducts associated with the single exposure have been eliminated. In the case of ethylene oxide adducts, nonsmokers as well as smokers reveal a distinct adduct background due to endogenously formed ethene from intestinal bacteria or from ethene in tobacco smoke, respectively $(10,28,32)$. Follow-up biomonitoring in this study has provided new in vivo human data to support the above-mentioned toxicokinetic considerations. As can be seen in the Figures 1 and 2, the elimination curve can reasonably be described with a linear fit during the first three post-exposure months, while the attenuation curve seems to level off near the end of and beyond the 120day interval. As the erythrocytes' life-span may vary to a certain degree, the asymptotically extended curve may be due to a fraction of older erythrocytes with haemoglobin adducts from the accidental exposure.
Nevertheless, the linear decline during the first postexposure months points to an almost complete elimination after about 120 days (range: 101 to 140 days), which is in very good accordance with expected kinetics. In an earlier study by Bader and Wrbitzky (31), a somewhat longer average elimination phase of 148 days was observed for acrylonitrile adducts. However, the database in that investigation was smaller than in the study presented here, as it comprised only samples from four individuals and three sampling times during the 120-day interval.

In this study, urinary cotinine and the acrylonitrile adduct $\mathrm{CEV}$ were analysed alongside with the ethylene oxide adducts. Both biomarkers were monitored in order to confirm the self-reported smoker status, but also to provide a measure for constant or changing smoking behaviours of the study participants. While both biomarkers showed a relatively large variability, the results can be interpreted in the way that individual smoking habits of the participants did not change significantly during the study interval. Therefore, the results of the last HEV analyses after about 160 days can reasonably be regarded as the individual adduct background values of the study participants. In one case (workerno. 1), the result of one HEV determination was available from a general survey three months before the accidental exposure. This earlier adduct level was $224 \mathrm{pmol} \mathrm{g}^{-1}$ globin as compared to the $164 \mathrm{pmol} \mathrm{g}^{-1}$ globin found 166 days after the accidental exposure. The variation of the mean value of these results $\left(30 \mathrm{pmol} \mathrm{g}^{-1}\right.$ globin $=15 \%$ of the $194 \mathrm{pmol} \mathrm{g}^{-1}$ globin mean value) is within the range of the analytical uncertainty of the adduct method. It seems reasonable to assume that both values reflect the same adduct background associated with cigarette smoking and the endogenous exposure.

Another important aspect of linearity of the adduct attenuation curve is that it allows for a back-calculation of the initial post-accidental adduct levels from samples collected several days or weeks after the exposure. The validity of this approach relies, however, on the exposure intensity. As the analytical method has an imprecision of about $12 \%$ (17), the additional adduct formation related to exposure should be at least higher than $\sim 25 \%$ of the background value, otherwise it may go undetected. Therefore, it seems advisable in the case of an accidental exposure to collect at least two samples, one in connection with the exposure and one after the 120-day interval in order to distinguish between additional and background exposure. If the first sample is significantly higher 
than the background value, considering the analytical imprecision, an extrapolation to the initial adduct concentration is warranted. Although increased adduct levels may be observed still weeks and even months after the exposure, in particular when the exposure was high, the collection of blood should be carried out as promptly as feasible.

A particularly difficult and yet untackled question is the assessment of adduct concentrations after single or accidental exposures. Current assessment values for adducts such as the EKA of the German DFG are based on the assumption of a steady-state condition, which is reached only after at least 120 days of exposure. Provided, e.g., that an individual is exposed to a similar ethylene oxide concentration for 8 hours a day, the adduct levels will accumulate and rise with a certain daily increment which is reflective of the daily absorbed dose. However, older erythrocytes are also removed constantly from the blood stream. Therefore, a steady-state is achieved only after one life-span of the erythrocytes (120 days) has elapsed, and the corresponding adduct level reflects the cumulative dose of 60 exposure days, or 60 daily increments $(12,21)$. The German EKA value for a daily exposure to $1 \mathrm{ppm}$ ethylene oxide is $90 \mu \mathrm{g} \mathrm{L}^{-1}$, or a rounded 3,900 $\mathrm{pmol} \mathrm{g}^{-1}$ globin (13). Therefore, a daily ( $8 \mathrm{~h}$ exposure) increment or 'ppm-equivalent' of $3,900 / 60=65 \mathrm{pmol} \mathrm{g}^{-1}$ globin can be calculated and used for the assessment of single or accidental ethylene oxide exposures.

In the current study, the initial adduct levels are equivalent to an 8-h-exposure of workers to 5 to 36 'ppm-equivalents'. Considering the 15 -min exposure interval (1/32 of an 8 -h-shift), these equivalents correspond to a short-term exposure of $160 \mathrm{ppm}$ to $1152 \mathrm{ppm}$ (300 $\mathrm{mg} \mathrm{m}^{-3}$ to $\left.2000 \mathrm{mg} \mathrm{m}^{-3}\right)$ a value well in line with the estimated EO concentration as discussed above on the basis of the released material, and also in accordance with the activation of the facility's gas alert system. Additionally, acute toxic effects of ethylene oxide as described by the workers are plausible for a short-term exposure to several hundred ppm EO.

In conclusion, the biomonitoring follow-up study has confirmed theoretical considerations on adduct kinetics in humans and enabled the evaluation of 'ppm-equivalents' for the assessment of short-term exposure incidents. This approach may further assist in a more widespread and extended application of protein adduct analysis for the monitoring of exposure to carcinogenic substances, including short-term accidental exposures, with the most significant practical advantage of offering a broad time frame for sampling.

\section{REFERENCES}

1. World Health Organization (WHO). Ethylene oxide. Environmental Health Criteria 55. Geneva: World Health Organization; 1985.

2. Deutsche Forschungsgemeinschaft (DFG). Ethylene oxide. In: Henschler D, editor. Occupational toxicants. Critical data evaluation for MAK values and classification of carcinogens. Commission for the Investigation of Health Hazards of Chemical Compounds in the Work Area. Vol. 5. Weinheim: VCH Verlagsgesellschaft; 1993. p. 182-92.

3. International Agency for Research on Cancer (IARC). Monographs on the evaluation of carcinogenic risks to humans. 1,3-Butadiene, Ethylene Oxide and Vinyl Halides (Vinyl Fluoride, Vinyl Chloride and Vinyl Bromide). Vol. 97. Lyon: IARC; 2008.

4. Angerer J, Bader M, Krämer A. Ambient and biochemical effect monitoring of workers exposed to ethylene oxide. Int Arch Occup Environ Health 1998;71:14-8.

5. Rosenberger W, Graubner G, Wrbitzky R, Bader M. [Untersuchungen zur Freisetzung von Ethylenoxid aus gassterilisierten neurochirurgischen Implantaten, in German]. Presentation on the occasion of the 49. Jahrestagung der Deutschen Gesellschaft für Arbeitsmedizin und Umweltmedizin (DGAUM). In: Kraus Th, Gube M, editors. 49. Jahrestagung der Deutschen Gesellschaft für Arbeitsmedizin und Umweltmedizin (DGAUM), 2009. Documentation on CD-ROM.

6. Gemeinsames Ministerialblatt (GMBl). [Bek. v. 2.8.10, Bekanntmachung von Empfehlungen für Biomonitoring bei Tätigkeiten mit krebserzeugenden Gefahrstoffen, in German]. GMBI 2010;62:1257-60.

7. Gemeinsames Ministerialblatt (GMBI). [TRGS 513 (Technische Regel für Gefahrstoffe) Tätigkeiten an Sterilisatoren mit Ethylenoxid und Formaldehyd, in German]. GMBI 2011;49-51:993-1018.

8. Norpoth K, Bolt HM. Ethylene oxide [BAT Value Documentation, 1995]. The MAK-Collection for Occupational Health and Safety [displayed 17 May 2012]. Available at http://onlinelibrary.wiley.com/doi/10.1002/3527600418. bb7521e0002/pdf

9. Bolt H. Ethylene oxide, Addendum [BAT Value Documentation, 2010]. The MAK-Collection for Occupational Health and Safety [displayed 17 May 2012]. Available at http://onlinelibrary.wiley.com/doi/10.1002/3527600418. bb7521e0005/pdf

10. Törnqvist M, Mowrer J, Jensen S, Ehrenberg L. Monitoring of environmental cancer initiators through hemoglobin adducts by a modified Edman degradation method. Anal Biochem 1986;154:255-66.

11. Lewalter J. N-alkylvaline levels in globin as a new type of biomarker in risk assessment of alkylating agents. Int Arch Occup Environ Health 1996;68:519-30.

12. Törnqvist M, Fred C, Haglund J, Helleberg B, Paulsson B, Rydberg P. Protein adducts: quantitative and qualitative aspects of their formation, analysis and applications. J Chromatogr B Analyt Technol Biomed Life Sci 2002;778:279308. 
13. Deutsche Forschungsgemeinschaft (DFG). List of MAK and BAT values 2011. Maximum Concentrations and Biological Tolerance Values at the Workplace. Report 47. Weinheim: Wiley-VCH; 2011.

14. Bailey E, Brooks AGF, Dollery CT, Farmer PB, Passingham BJ, Sleightholm M, Yates DW. Hydroxyethylvaline adduct formation in haemoglobin as a biological monitor of cigarette smoke intake. Arch Toxicol 1988;62:247-53.

15. Persson KA, Berg S, Törnqvist M, Scalia-Tomba GP, Ehrenberg L. Note on ethene and other low-molecular weight hydrocarbons in environmental tobacco smoke. Acta Chem Scand B 1988;42:690-6.

16. Bader M, Lewalter J, Angerer J. Analysis of N-alkylated amino acids in human hemoglobin: evidence for elevated $\mathrm{N}$-methylvaline levels in smokers. Int Arch Occup Environ Health 1995;67:237-42.

17. van Sittert NJ, Angerer J, Bader M, Blaskewicz M, Ellrich D, Krämer A, Lewalter J. N-2-cyanoethylvaline, N-2hydroxyethylvaline, $\mathrm{N}$-methylvaline (as evidence of exposure to acrylonitrile, ethylene oxide and well as methylating agents). In: Angerer J, Schaller KH, editors. Analyses of hazardous substances in biological materials. Vol. 5. Weinheim: Wiley-VCH; 1997. p. 181-210.

18. Osterman-Golkar S, Ehrenberg L, Segerbäck D, Hällström I. Evaluation of genetic risks of alkylating agents. II. Haemoglobin as a dose monitor. Mutat Res 1976;34:1-10.

19. Osterman-Golkar S. Dosimetry of ethylene oxide. IARC Sci Publ 1988;89:249-57.

20. Granath F, Ehrenberg L, Törnqvist M. Degree of alkylation of macromolecules in vivo from variable exposure. Mutat Res 1992;284:297-306.

21. Fennell TR, Sumner SCJ, Walker VE. A model for the formation and removal of hemoglobin adducts. Cancer Epidemiol Biomarkers Prev 1992;1:213-9.

22. Schettgen T, Broding HC, Angerer J, Drexler H. Hemoglobin adducts of ethylene oxide, propylene oxide, acrylonitrile and acrylamide-biomarkers in occupational and environmental medicine. Toxicol Letters 2002;34:65-70.

23. Bader M, Hecker H, Wrbitzky R. Querschnittstudie zur ernährungs- und tabakrauchbedingten Belastung der Allgemeinbevölkerung mit Acrylamid [Cross-sectional study on dietary and smoking related exposure to acrylamide, in German]. Dtsch Ärztebl 2005;39:B2231-4.

24. Müller M, Heinrich-Ramm R, Hoppe HW. Cotinine. In: Angerer J, Schaller KH editors. Analyses of hazardous substances in biological materials. Vol. 8. Weinheim: WileyVCH; 2003. p. 53-65.

25. Tsikas D, Wolf A, Mitschke A, Gutzki FM, Will W, Bader M. GC-MS determination of creatinine in human biological fluids as pentafluorobenzyl derivative in clinical studies and biomonitoring: Interlaboratory comparison in urine with Jaffé, HPLC and enzymatic assays. J Chromatogr B Analyt Technol Biomed Life Sci 2010;878:2582-92.

26. BASF Chemical Emergency Medical Guidelines. Ethylene oxide [displayed 17 May 2012]. Available at http://www. basf.com/group/corporate/en/sustainability/ employees/occupational-medicine/responsiblecare

27. UBA (Umweltbundesamt, German Federal Environment Agency) Umwelt-Survey 1998, Band III: HumanBiomonitoring. Stoffgehalte in Blut und Urin der Bevölkerung in Deutschland. WaBoLu-Hefte 2002;1:214.

28. Törnqvist M, Gustafsson B, Kautiainen A, Harms-Ringdahl M, Granath F, Ehrenberg L. Unsaturated lipids and intestinal bacteria as sources of endogenous production of ethene and ethylene oxide. Carcinogenesis 1989;10:39-41.

29. Walker VE, MacNeela JP, Swenberg JA, Turner MJ, Fennell TR. Molecular dosimetry of ethylene oxide: Formation and Persistence of $\mathrm{N}$-(2-hydroxyethyl)valine in hemoglobin following repeated exposures of rats and mice. Cancer Res 1992;52:4320-7.

30. Granath F, Westerholm R, Peterson A, Törnqvist M, Ehrenberg L. Uptake and metabolism of ethene studied in a smoke-stop experiment. Mutat Res 1994;313:285-91.

31. Bader M, Wrbitzky R. Follow-up biomonitoring after accidental exposure to acrylonitrile - Implications for protein adducts as a dose monitor for short-term exposures. Toxicol Lett 2006;162:125-31.

32. Filser JG, Denk B, Törnqvist M, Kessler W, Ehrenberg L. Pharmacokinetics of ethylene oxide in man; body burden with ethylene oxide and hydroxyethylation of hemoglobin due to endogenous and environmental ethylene. Arch Toxicol 1992;66:157-63. 


\section{Sažetak}

\section{ANALIZA PROTEINSKIH ADUKATA KAO BIOMARKERA KRATKOTRAJNE IZLOŽENOSTI ETILEN OKSIDU I REZULTATI BIOMONITORINGA}

U radu su prikazani rezultati biomonitoringa provedenog neposredno nakon akcidentalnog izlaganja šestorice radnika etilen oksidu i studije praćenja (follow up) provedene u cilju procjene kinetike razgradnje proteinskih adukata i utvrđivanja razlika nakon kratkotrajne izloženosti i izlaganja čimbenicima iz okoliša kao što je duhanski dim. U tu smo svrhu tijekom petomjesečnoga razdoblja nakon nezgode pratili smanjenje koncentracije hemoglobinskog adukta $\mathrm{N}$-2-hidroksietilvalina usporedo s mjerenjem razina $\mathrm{N}$-2cijanoetilvalina i kotinina u mokraći, koji su pouzdani biomarkeri za dokazivanje pušenja duhana. Studija praćenja je pokazala da su koncentracije adukata etilen oksida značajno porasle nakon kratkotrajnoga izlaganja visokoj razini etilen oksida. U početnom biomonitoringu svih radnika izmjerene su razine $\mathrm{N}$-2hidroksietilvalina iznad 500 pmol g-1 globina, s maksimalnom vrijednošću od oko $2400 \mathrm{pmol} \mathrm{g}^{-1}$ globina. Ti su podaci usporedivi s vrijednostima njemačkih normi ekvivalenata izlaganja kancerogenim tvarima (EKA) od $90 \mu \mathrm{g} \mathrm{L}^{-1} \mathrm{krvi}\left(\sim 3900 \mathrm{pmol} \mathrm{g}^{-1}\right.$ globina) kroz osmosatno dnevno izlaganje koncentraciji od 1 ppm etilen oksida. Razine adukata smanjile su se u skladu s očekivanom kinetikom nultoga reda za jednokratno izlaganje. Koncentracije $N$-2-hidroksietilvalina izmjerene u krvi radnika nakon petomjesečnoga praćenja mogu se povezati s njihovim osobnim pušačkim navikama. Rezultati toga istraživanja pokazuju da čak i kratkotrajna izloženost etilen oksidu može znatno povisiti razine adukata hemoglobina. Premda se u zdravstvenom nadzoru u okviru medicine rada proteinski adukti i njihove vrijednosti razmatraju u procjeni dugotrajnoga izlaganja, oni se mogu koristiti i za praćenje akcidentalnih izlaganja. U tim slučajevima izračun dnevnih vrijednosti (tzv. ppm-ekvivalenata) može poslužiti za usporedbu s postojećim procijenjenim vrijednostima.

KLJUČNE RIJEČI: akcidentalna izloženost, kinetika adukata hemoglobina, profesionalna izloženost

\section{CORRESPONDING AUTHOR:}

PD Dr. Michael Bader

BASF SE, Occupational Medicine \& Health Protection 67056 Ludwigshafen, Germany

E-mail: michael.bader@basf.com 